\title{
Modeling a Distributed Power Flow Controller with a PEM Fuel Cell for Power Quality Improvement
}

\author{
Jaydeep Chakravorty \\ Electrical Engineering Department \\ Indus University \\ Ahmedabad, India \\ jaydeepchak@yahoo.co.in
}

\author{
Jyoti Saraswat \\ Electrical Engineering Department \\ Baddi University \\ Himachal Pradesh, India \\ jyotisara@gmail.com
}

\author{
Vinay Bhatia \\ HoD Electronics and \\ Communication Engineering \\ Baddi University \\ Himachal Pradesh, India
}

\begin{abstract}
Electrical power demand is increasing at a relatively fast rate over the last years. Because of this increasing demand the power system is becoming very complex. Both electric utilities and end users of electric power are becoming increasingly concerned about power quality. This paper presents a new concept of distributed power flow controller (DPFC), which has been implemented with a proton exchange membrane (PEM) fuel cell. In this paper, a PEM fuel cell has been simulated in Simulink/MATLAB and then has been used in the proposed DPFC model. The new proposed DPFC model has been tested on a IEEE 30 bus system.
\end{abstract}

\section{Keywords-DPFC; PEM; power quality}

\section{INTRODUCTION}

Power quality improvement is a major concern of the power industry [1]. To improve power quality, custom power devices are used [2]. FACTS devices, such as unified power flow controller (UPFC) and synchronous static compensator (STATCOM), are used to alleviate the disturbance and improve the power system quality and reliability $[3,4]$. The distributed power flow controller (DPFC) is a device in the FACTS family, derived from the UPFC. Compared with the UPFC, DPFC has the same controlling capability to change all the parameters within the transmission system. In case of DPFC the commonly connected DC link between series and shunt converter is eliminated. Fuel cells are electrochemical devices that convert chemical energy of a fuel directly to electric energy, without any moving parts $[5,6]$. Compared with the other fuel celltypes, PEMFC show promising results with advantages such as low temperature, high power density, fast response, and zero emission if run with pure hydrogen [7]. In this paper, the DC source that is used in DPFC has been replaced by a PEM fuel cell. The performance of the proposed new model of DPFC is then compared with some existing conventional DPFC models to check its performance.

\section{PRoton EXCHANGE MEMBRANE FUEL CELL}

There are several models of fuel cells available in the literature. These range from stationary to dynamic models [810]. PEM fuel cell consists of a solid polymerelectrolyte sandwiched between two electrodes (anode and cathode). In the electrolyte, only ions canexit and electrons are not allowed to pass through. So, the flow of electrons needs a path like anexternal circuit from the anode to the cathode to produce electricity because of a potential difference between the anode and cathode. The overall electrochemical reactions for a PEM fuel cell fed witha hydrogen-containing anode and an oxygen containing cathode are:

$$
\begin{aligned}
& \text { Anode: } 4 \mathrm{H}^{+}+4 \mathrm{e}^{-}=2 \mathrm{H}_{2} \\
& \text { Cathode: } \mathrm{O}_{2}+4 \mathrm{H}^{+}+4 \mathrm{e}^{-}=2 \mathrm{H}_{2} \mathrm{O} \\
& \text { Overall: } 2 \mathrm{H}_{2}+\mathrm{O}_{2}=2 \mathrm{H}_{2} \mathrm{O}+\text { electricity }+ \text { heat }
\end{aligned}
$$

The output stack voltage $\mathrm{V}$ is given by the expression

$$
\mathrm{V}=\mathrm{N}_{0}\left[\mathrm{E}_{0}+\frac{\mathrm{RT}}{2 \mathrm{~F}}\left[\ln \frac{\mathrm{P}_{\mathrm{H} 2} \mathrm{P}_{\mathrm{O} 2}^{0.5}}{\mathrm{P}_{\mathrm{H} 2 \mathrm{O}}}\right]\right]-\mathrm{Bln} \mathrm{CI}-\mathrm{IR}_{\text {int }}
$$

Where $\mathrm{P}_{\mathrm{H} 2}$ is partial hydrogen pressure, $\mathrm{P}_{\mathrm{O} 2}$ is partial oxygen pressure, $\mathrm{P}_{\mathrm{H} 2 \mathrm{O}}$ is partial water pressure, $\mathrm{R}_{\text {int }}$ is the internal resistance, $\mathrm{I}$ is the fuel cell current, $\mathrm{B}$ and $\mathrm{C}$ are constants, $\mathrm{F}$ is the Faraday constant, $\mathrm{R}$ gases universal constant.The SIMULINK block of PEM fuel cell is shown in Figure 1.

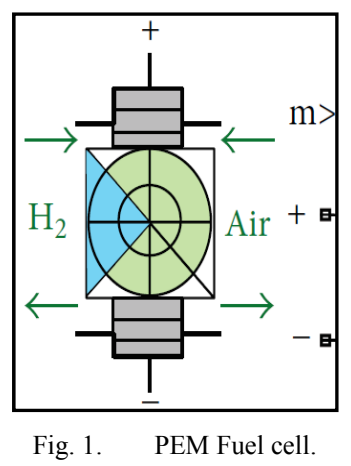

\section{Z SOURCE INVERTER}

In the proposed model of DPFC with PEM fuel cell, a Z Source Inverter (ZSI) has been used. The ZSI has the unique feature that it can boost/buck the output voltage by introducing shoot through operation mode, which is forbidden in traditional voltage source inverters [11]. With this feature, ZSI provides a cheaper, simpler, buck-boost inversion by single power 
conversion stage, strong EMI immunity and low harmonic distortion [12]. The model of $Z$ source inverter for fuel cell application is shown in Figure 2. The DC link voltage of $Z$ source inverter is shown in Figure 3. The alternate output voltage of the $\mathrm{z}$ source inverter without filter is shown in Figure 4. The FFT analysis of $\mathrm{Z}$ source inverter is shown in Figure 5. As shown, $\mathrm{THD}=287.23 \%$ and fundamental $=36.35$. To compensate this, an LC filter is employed. The filtered output is shown in Figure 6. As shown, THD is now $0.66 \%$ and fundamental $=1056$. The FFT analysis of $Z$ source inverter with filter is shown in Figure 7.

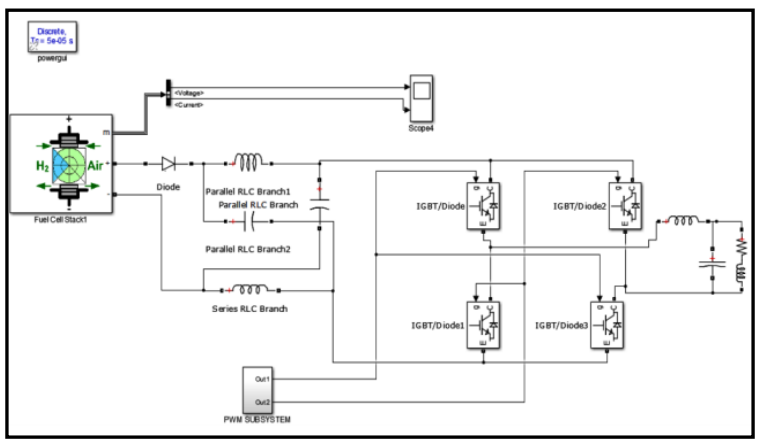

Fig. 2. Simulink Model of ZSI with PEM fuel cell

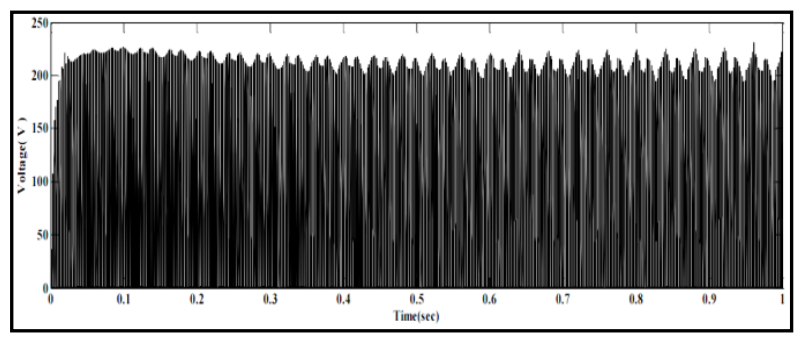

Fig. 3. DC link voltage of ZSI

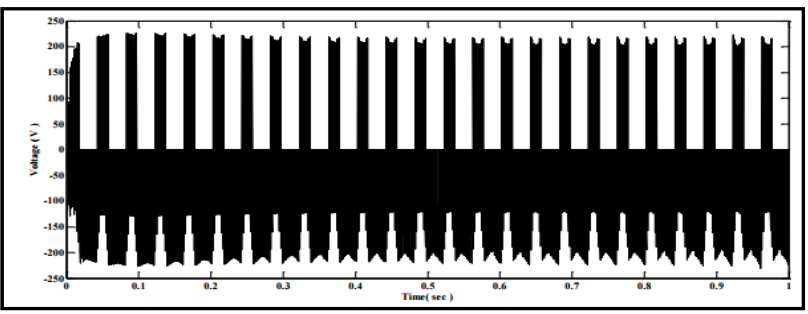

Fig. 4. Alternating Output Voltage on Inverter.

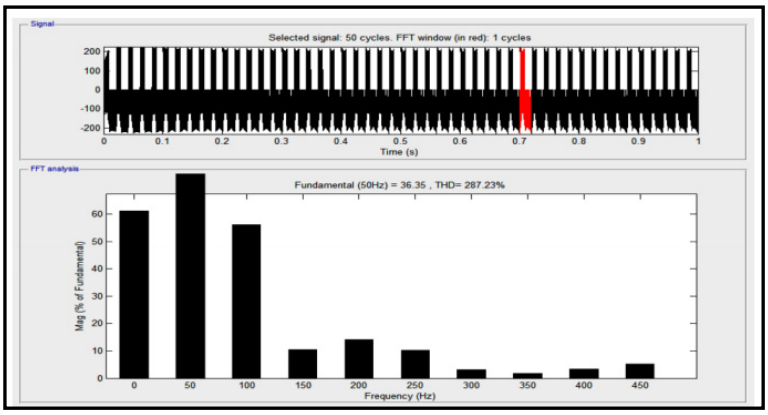

Fig. 5. FFT analysis of $\mathrm{Z}$ source Invereter.

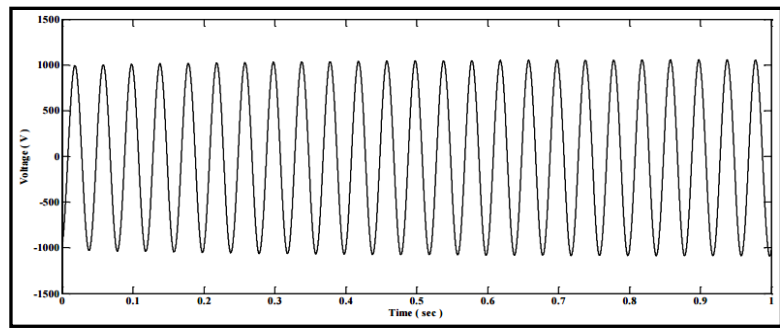

Fig. 6. Filtered Output Voltage of Z Source Inverter.

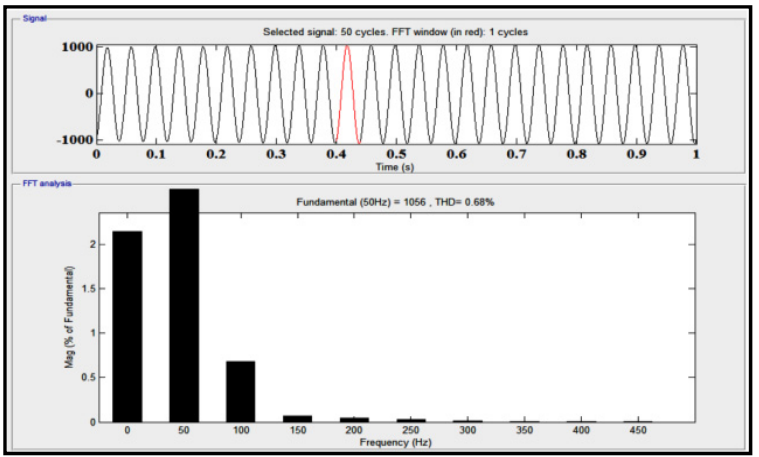

Fig. 7. Filtered Output Voltage of Z Source Inverter.

\section{PROPOSED MODELOF DPFC}

The block diagram of DPFC is shown in Figure 8. It mainly consists of five units namely, fundamental frequency model, $3^{\mathrm{rd}}$ harmonic model, series converter model, shunt converter model and control unit. In the Figure, $V_{s}$ is the sending end voltage, $V_{r}$ is the receiving end voltage, $I_{1}$ is the first harmonic current, $I_{3}$ is the third harmonic current, $\mathrm{V}_{\mathrm{se}, 1}$ is the voltage at fundamental frequency injected by the series converter, $\mathrm{V}_{\mathrm{se}, 3}$ is the voltage at third frequency injected by the series converter, $\mathrm{V}_{\text {se,ref }}$ is the modulated amplitude of the reference AC signal, generated by series control unit, $\mathrm{V}_{\mathrm{sh} \text {,ref }}$ is the modulated amplitude of the reference AC signal, generated by shunt control unit. $\mathrm{V}_{\mathrm{sh}, 1}$ and $\mathrm{V}_{\mathrm{sh}, 3}$ are the voltage magnitudes of the $\mathrm{i}^{\text {th }}$ harmonic of the shunt converters [10].

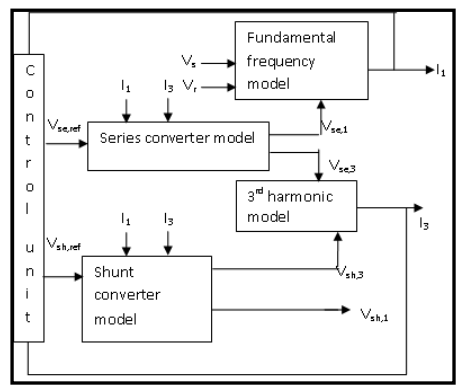

Fig. 8. Dlock diagram of DPFC.

The implementation of the five mentioned above blocks is presented below. The model of the fundamental frequency network has been modeled from (2):

$$
\left[V_{s}\right]-\left[V_{r}\right]-\left[V_{s e, 1}\right]=\left[Z_{1}\right] \times\left[I_{1}\right]
$$


where $V_{s}, V_{r}, V_{\text {se, } 1}, Z_{1}$ and $I_{1}$ are the matrices of the three phase voltages, impedance at first harmonic and current respectively. The MATLAB/simulink model of the third harmonic network has been modeled from (3):

$\left[V_{s \mathrm{~h}, 3}\right]-\left[V_{s e, 3}\right]=\left[Z_{3}\right] \times\left[I_{3}\right]$

Where $\mathrm{V}_{\mathrm{sh}, 3}, \mathrm{~V}_{\mathrm{se}, 3}, \mathrm{Z}_{3}$ and $\mathrm{I}_{3}$ are the matrices of three phase third harmonic voltages, impedance and current respectively

The series converter model has been modeled modeled from (4).
$C_{s e} \frac{d V_{d c_{s e}}}{d t}=\frac{1}{2}\left(V_{s e_{-} 1 \_d \_r e f} \times I_{d_{-} 1}+V_{s e_{-} 1 \_q \_r e f} \times I_{q_{-} 1}\right)+$

$\frac{1}{2}\left(V_{s e \_3 \_d \_r e f} \times I_{d \_3}+V_{s e \_3 \_q \_r e f} \times I_{q_{-} 3}\right)$

The shunt converter model is obtained from (5):

$$
\begin{aligned}
& \mathrm{C}_{\mathrm{sh}} \frac{\mathrm{dV}_{\mathrm{dc}} \mathrm{sh}}{\mathrm{dt}}=\frac{3}{2}\left(\mathrm{~V}_{\text {sh_1_d_ref }} \times \mathrm{I}_{\text {sh_d_1 }}+\mathrm{V}_{\text {sh_1_q_ref }} \times \mathrm{I}_{\text {sh_q_1 }}\right)- \\
& \frac{1}{2}\left(\mathrm{~V}_{\mathrm{sh} \_3 \_\mathrm{d} \_ \text {ref }} \times \mathrm{I}_{\text {sh_d_3 }}+\mathrm{V}_{\text {sh_3_q_ref }} \times \mathrm{I}_{\text {sh_q_3 }}\right)
\end{aligned}
$$

The complete DPFC model with PEM fuel cell and $\mathrm{Z}$ inverteris shown in Figure 9. The model is then used on a IEEE 30 bus system.

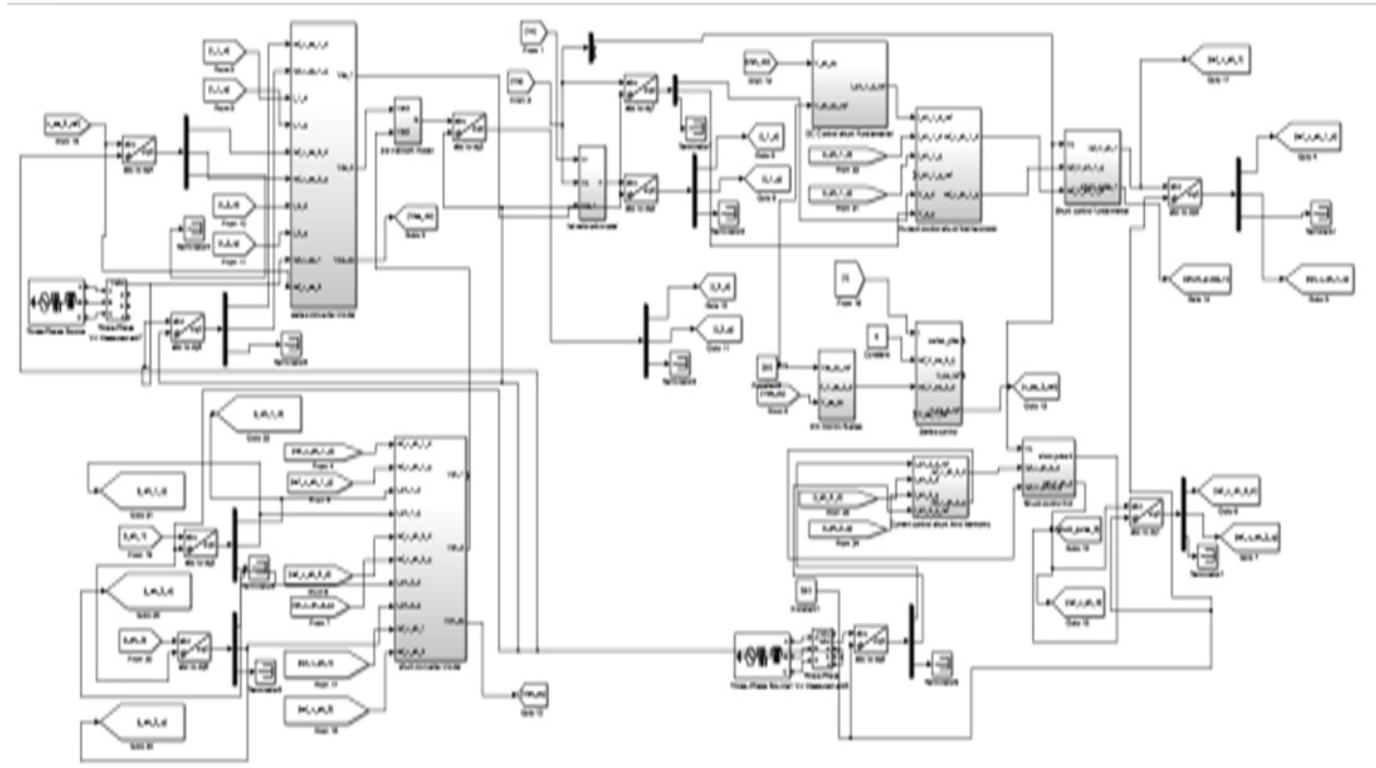

Fig. 9. Proposed DPFC Model

\section{RESULTS}

The simulated results for the proposed circuit are shown in Figures 10-15 whereas the performance of the proposed DPFC when used in the IEEE 30 bus system is shown in Figures 16 to 19.

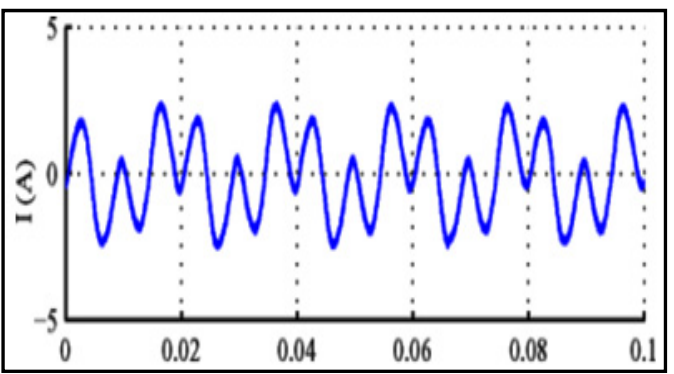

Fig. 10. DPFC steady state line current

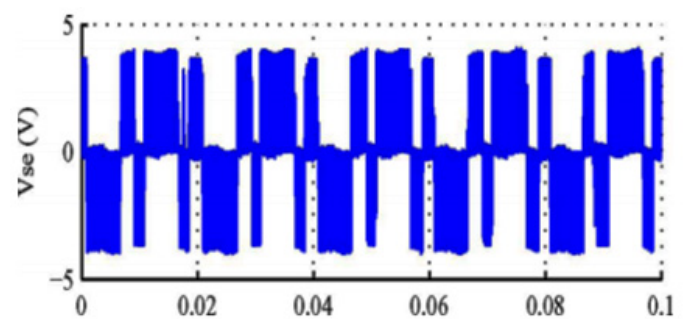

Fig. 11. DPFC steady state series converter voltage

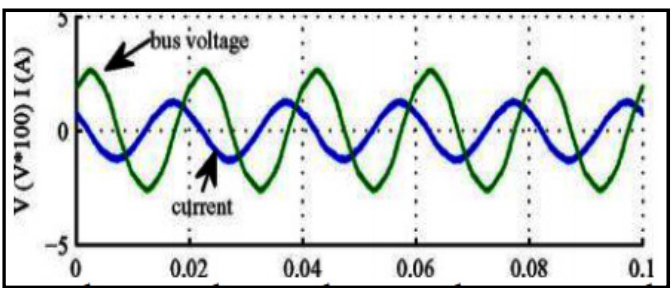

Fig. 12. DPFC steady state bus voltage and current at delta side of the transformer. 


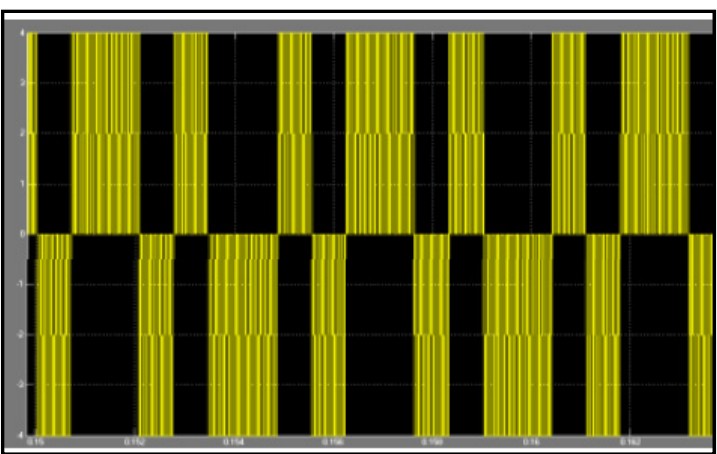

Fig. 13. Series converter voltage

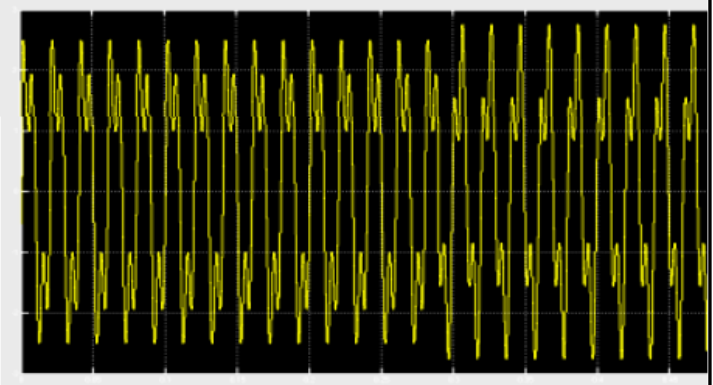

Fig. 14. Line current

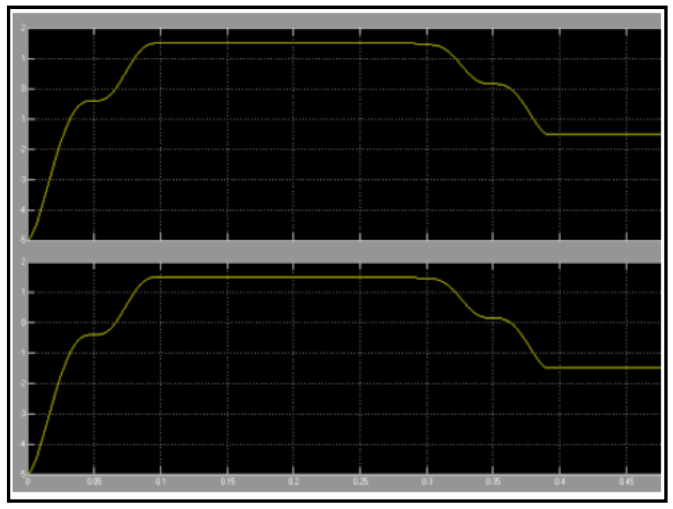

Fig. 15. Active and reactive power injected by series conveter at fundamental frequency.

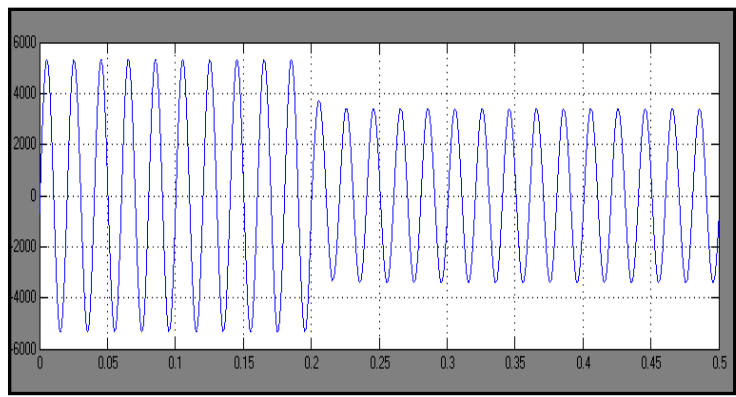

Fig. 16. Load voltage without DPFC

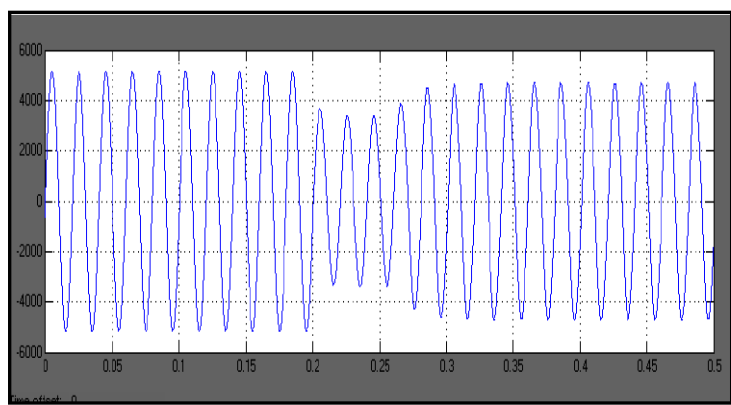

Fig. 17. Load voltage with DPFC

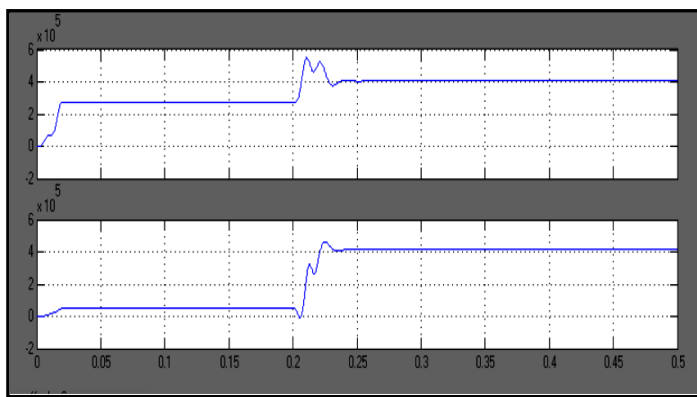

Fig. 18. Realand reactive without DPFC

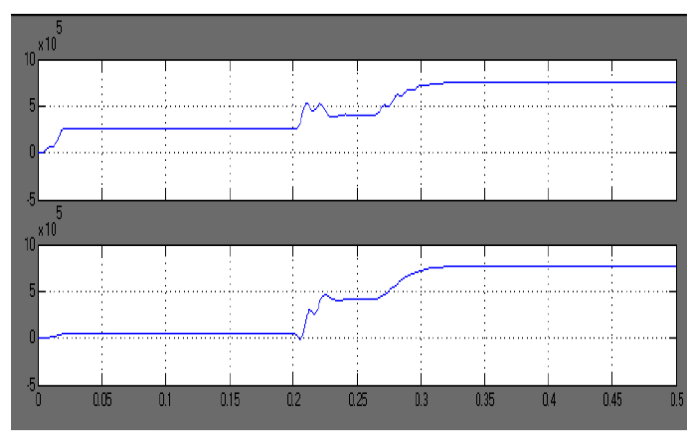

Fig. 19. Realand reactive with DPFC

\section{CONCLUSION}

In this paper, a new model of DPFC with a PEM fuel cell and a $\mathrm{Z}$ source inverter has been presented. The performance of $\mathrm{Z}$ source inverter was tested and then it was used in the DPFC model with PEM fuel cell. The proposed model was applied to an IEEE 30 bus system. The performance of the system was checked with and without the proposed model. The simulations were performed in MATLAB/Simulink. The result shows that the proposed DPFC gives an acceptable performance in regard of power quality improvement. To further improve the model, the optimal placement of the proposed DPFC model should be considered.

\section{REFERENCES}

[1] S. Masoud Barakati, A. Khoshkbar Sadigh, E. Mokhtarpour, "Voltage Sag and Swell Compensation with DVR Based on Asymmetrical Cascade Multicell Converter", North American Power Symposium (NAPS), pp.1-7, 2011 
[2] M. A. Hannan, A. Mohamed, "PSCAD/EMTDC Simulation of Unified Series-Shunt Compensator for Power Quality Improvement", IEEE Transactions on Power Delivery, Vol. 20, No. 2, pp. 1650-1656, 2005

[3] A. L. Olimpo, E. Acha, "Modeling and analysis of custom power systems by PSCAD/EMTDC", IEEE Transactions on Power Delivery, Vol. 17, No. 1, pp. 266-272, 2002

[4] P. Pohjanheimo, E. Lakervi, "Steady state modeling of custom power components in power distribution networks", IEEE Power Engineering Society Winter Meeting, Vol. 4, pp. 2949-2954, 2000

[5] C. Spiegel, Pem Fuel Cell Modeling And Simulation Using Matlab, Elsevier, 2011

[6] G. Bucci, E. Fiorucci, F. Ciancetta, F. Veglio, "Experimental Characterization and Modeling of PEM Fuel Cells under Dynamic Load Variations", Vol. 5, No. 2, pp. 75-84, 2010

[7] M. A. R. Sadig Al-Baghdadi, "Modelling of Proton Exchange Membrane Fuel Cell Performance Based on Semi-Empirical Equations", Renewable Energy, Vol. 30, No. 10, pp. 1587-1599, 2005

[8] M. Uzunoglu, M. S. Alam, "Dynamic Modelling, Design and Simulation of a Combined PEM Fuel Cell and Ultra capacitor System for StandAlone Residential Application", IEEE Transactions on Energy Conversion, Vol. 21, No. 3, pp. 767-775, 2006

[9] J. Padulles, G. W. Ault, J. R. McDonald, "An Approach to the Dynamic Modeling of Fuel CellCharacteristics for Distributed Generation Operation”, IEEE-PES Winter Meeting, Vol. 1, pp.134-138, 2000

[10] C. Wang, M. H. Nehrir, S. R. Shaw, "Dynamic model and model validation for PEM fuel cells using electrical circuits", IEEE Transactions on Energy Conversion, Vol. 20, No. 2, pp. 442-451, 2005

[11] J. Rabi, R. Arumugam, "Harmonics study and comparison of Z-source inverter", The American Journal of Applied Sciences, Vol. 2, No. 10, pp. 1418-1426, 2010

[12] A. Ajam, B. Soulat, A. Safari, "A Novel Modelling and Controlling of Distributed Power Flow Controller (DPFC) Base on PSO Algorithm", ECTI Transactions on Electrical Engineering, Electronics and Communications, Vol. 11, No. 1, pp. 1-8, 2014

[13] A. Jamshidi, S. Masoud Barakati, M. Moradi Ghahderijani, "Impact of Distributed Power Flow Controller to ImprovePower Quality Based on Synchronous Reference Frame Method", IACSIT International Journal of Engineering and Technology, Vol. 4, No. 5, pp. 581-585, 2012 